\title{
Phosphate Treatment of Hypercalcaemia Due to Carcinoma
}

\author{
N. THALASSINOS,* M.D. ; G. F. JOPLIN,* PH.D., M.R.C.P.
}

Brit. med.F., 1968, 4, 14-19

\begin{abstract}
Summary : Thirteen patients with hypercalcaemia due to carcinoma received inorganic phosphate, orally or intravenously, as palliative treatment for their high serum calcium levels. The serum calcium promptly fell in all patients fully treated, and there was a striking clinical improvement in most patients. The blood urea was usually unchanged or became nearer to normal, while the serum phosphate altered variably. Only two of the eight patients who were studied at necropsy had microscopical nephrocalcinosis; corneal calcification was evident in both before phosphate treatment was started.

This oral inorganic phosphate ( 1 gramme thrice daily) is a safe and effective means of treating hypercalcaemia due to carcinoma. An intravenous infusion of 1 gramme over eight hours may sometimes be required initially for patients who are vomiting.
\end{abstract}

\section{Introduction}

Part of the palliation of the effects of cancer is the treatment of any associated hypercalcaemia, estimated to occur in 10$20 \%$ of patients with the more common cancers (Watson, 1966). Clearly, the most effective means of relieving the hypercalcaemia is either by removal of the tumour (Plimpton and Gellhorn, 1956) or by temporary suppression of the malignant growth such as by radiotherapy (Albright and Reifenstein, 1948), cytotoxic drugs (Drivsholm and Videbæk, 1966), or alteration of the endocrine environment as is seen in some patients with disseminated breast cancer after yttrium-90 pituitary implantation (Joplin, 1965). Unfortunately, these measures often fail with a cancer which has reached the stage of causing hypercalcaemia, and so the relief of the latter becomes $a$ problem in its own right.

Though the clinical effects of a raised serum calcium are well known, they are unfortunately rather non-specific; lassitude, anorexia, nausea, and vomiting are indistinguishable from the general effect of advanced cancer, though polyuria, thirst, and dehydration may prompt a check on the serum calcium. Ultimately stupor and coma (Henson, 1966) follow with uraemia ; and indeed it was not until this critical stage had been reached that some patients of the present study were found io be hypercalcaemic.

A variety of measures have been used for the relief of hvpercalcaemia of malignant disease persisting after rehydration. These include corticosteroids (Connor et al., 1956 ; Watson, 1964), intravenous sodium citrate (Kennedy et al., 1953) or sodium sulphate (Lemann and Mehr, 1965 ; Chakmakjian and Bethune, 1966), calcitonin (Foster et al., 1968), and intravenous or oral inorganic phosphate. The present paper describes the results from phosphate administration in 13 such patients with malignant disease.

The effect of phosphate, whether given orally or intravenously, on the serum calcium concentration in normal animals has long been recognized (Binger, 1917-18; Salvesen et al., 1924). The therapeutic use of phosphate to lower a raised serum calcium in humans was first reported by Bulger \footnotetext{
* Department of Medicine, Royal Postgraduate Medical School, London
W.12.
}

et al. (1931) in two hyperparathyroid patients, and its effectiveness was confirmed by Albright et al. (1932) in another two hyperparathyroid patients. Phosphate therapy was then largely abandoned, possibly because of the theoretical fear that it might produce extraskeletal calcification. Recently, however, it has again come into use in the treatment of otherwise untreatable hypercalcaemia (Goldsmith and Ingbar, 1966; Hebert et al., 1966 ; Kahil et al., 1967 ; Kistler, 1967 ; Massry et al., 1968).

\section{Methods}

There were 13 patients with hypercalcaemia due to malignant disease. Certain clinical particulars are shown in the Table. In five patients skeletal $x$-ray films showed no evidence of bone deposits; nor were bone metastases found in any of these at necropsy.

\section{Clinical Procedure}

As soon as hypercalcaemia was found all patients were placed on a low calcium diet, consisting of a normal menu but excluding milk and milk products ( $<500 \mathrm{mg}$. calcium/day); in fact, few patients were eating any food at all. In all cases at least two days had elapsed between formalizing the calcium restriction and beginning phosphate. At the same time a fluid intake of at least 3 litres per day was begun, initially using normal saline intravenously in the 10 cases where vomiting precluded the oral route. In most of the cases (10) rehydration had been started at least three days before instituting phosphate.

Oral phosphate was administered when the clinical condition permitted; otherwise the intravenous route was used. In all the patients a fluid intake of 3 litres daily was aimed at, and continued during the phosphate treatment.

Oral Preparation.-A neutral phosphate mixture was usednamely, $\mathrm{Na}_{2} \mathrm{HPO}_{4}$ (anhydrous) 3.66 g., $\mathrm{NaH}_{2} \mathrm{PO}_{1} .2 \mathrm{H}_{2} \mathrm{O} 1 \mathrm{~g}$., orange syrup $16 \mathrm{ml}$., purified water to $60 \mathrm{ml}$. $60 \mathrm{ml}$. of this mixture contains $1 \mathrm{~g}$. of elemental phosphorus. The standard daily dose was $180 \mathrm{ml}$., distributed as evenly as possible around the 24 hours. Seven patients were able to take at least this amount, but sometimes only $60 \mathrm{mi}$. could be taken in a day, owing to nausea or diarrhoea.

Intravenous Preparation.-The formulation of Goldsmith and Ingbar (1966) was used-namely, $\mathrm{Na}_{2} \mathrm{HPO}_{4} 0.081$ mole and $\mathrm{KH}_{2} \mathrm{lO}_{4} 0.019$ mole in 1 litre of distilled water. One litre of this solution contains 100 millimoles of elemental phosphorus ( 3.1 g.), $162 \mathrm{mEq}$ of sodium, and $19 \mathrm{mEq}$ of potassium; the osmolality is $240 \mathrm{mOsm} / \mathrm{kg}$. and the $p H 7.4$. Our standard intravenous dose consisted of $330 \mathrm{ml}$. of this solution (supplying about $1 \mathrm{~g}$. of elemental phosphorus) given as an infusion over six to eight hours. In no patient was more than one such dose given in one day, and the most that was ever required to reduce the serum calcium to near normal was two days of treatment. Once vomiting ceased the oral route was used.

Courses of Treatment Studied.-Once a normal serum calcium was achieved, phosphate co:uld be discontinued. After a varying interval, depending on whether other treatment was effective, recurrence of hypercalcaemia necessitated a further course in five patients. Reduction in oral phosphate dosage, 
Effect of Phosphate Treatment

\begin{tabular}{|c|c|c|c|c|c|c|c|c|c|c|c|c|c|c|c|c|c|c|}
\hline \multirow{3}{*}{$\begin{array}{l}\text { Case } \\
\text { No. }\end{array}$} & \multirow{3}{*}{$\begin{array}{l}\text { Age } \\
\text { and } \\
\text { Sex }\end{array}$} & \multirow{3}{*}{ Type of Carcinoma } & \multirow{3}{*}{$\begin{array}{l}\text { Bone } \\
\text { Deposits } \\
\text { on } \\
X \text {-ray }\end{array}$} & \multirow{3}{*}{$\left|\begin{array}{c}\text { No. of } \\
\text { Course }\end{array}\right|$} & \multirow{2}{*}{\multicolumn{2}{|c|}{$\begin{array}{l}\text { Therapy } \\
\text { Total Phosphate } \\
\text { given (g. of P) } \\
\text { to Produce } \\
\text { Maximal Effect } \\
\end{array}$}} & \multirow{2}{*}{\multicolumn{2}{|c|}{$\begin{array}{c}\text { Serum } C a \\
\text { mEq } \\
(4 \cdot 5-5 \cdot 5)\end{array}$}} & \multirow{2}{*}{\multicolumn{2}{|c|}{$\begin{array}{c}\text { Serum POO4 } \\
\text { mEq/1.1 } \\
(1 \cdot 4-2 \cdot 6)\end{array}$}} & \multicolumn{8}{|c|}{ Biochemical Effects Seen* } \\
\hline & & & & & & & & & & & \multicolumn{2}{|c|}{$\begin{array}{c}\substack{\text { Blood } \\
\text { Urea } \\
\text { mg./1100 ml. } \\
(\leqslant 40)} \\
\end{array}$} & \multicolumn{2}{|c|}{$\begin{array}{c}\text { Serum Alkaline } \\
\text { Phosphatase } \\
\text { K.A.u.lom m. } \\
(\leqslant 13)\end{array}$} & \multicolumn{2}{|c|}{$\begin{array}{l}\text { Drop in } \\
\text { Serum Ca }\end{array}$} & \multicolumn{2}{|c|}{$\begin{array}{c}\text { Days } \\
\text { Required to } \\
\text { Produce } \\
\text { Fall in } \\
\text { Serum Ca }\end{array}$} \\
\hline & & & & & Oral & I.V. & $\begin{array}{c}\text { Pre- } \\
\text { phos.- } \\
\text { phate }\end{array}$ & $\begin{array}{c}\text { On } \\
\text { phos- } \\
\text { phate }\end{array}$ & $\begin{array}{l}\begin{array}{c}\text { Pre- } \\
\text { phoss } \\
\text { phate }\end{array} \\
\end{array}$ & $\begin{array}{c}\text { On } \\
\text { phos- } \\
\text { phate }\end{array}$ & $\begin{array}{c}\text { Pre- } \\
\text { phos- } \\
\text { phate }\end{array}$ & $\begin{array}{c}\begin{array}{c}\text { On } \\
\text { phos- } \\
\text { phate }\end{array} \\
\end{array}$ & $\begin{array}{c}\text { Pre-. } \\
\text { phos- } \\
\text { phate }\end{array}$ & $\begin{array}{c}\text { On } \\
\text { phos- } \\
\text { phate }\end{array}$ & $\mathrm{mEq} / \mathrm{l}$. & $\%$ & $\begin{array}{l}\text { Max. } \\
\text { Fall } \\
\end{array}$ & $\begin{array}{l}\text { First } \\
\text { Effect }\end{array}$ \\
\hline 1 & $62 \mathrm{M}$ & $\begin{array}{l}\text { Squamous cell, } \\
\text { bronchus }\end{array}$ & No & 1 & 29 & - & 7.9 & $5 \cdot 3$ & 2.9 & 2.8 & 78 & 54 & 7 & 6 & 2.6 & 33 & 9 & 3 \\
\hline 2 & $52 \mathrm{M}$ & $\begin{array}{l}\text { Squamous cell, } \\
\text { bronchws }\end{array}$ & Yes & 1 & 11 & - & $7 \cdot 2$ & 6.0 & 2.5 & 2.6 & 46 & 42 & - & - & $1 \cdot 2$ & 17 & 3 & 2 \\
\hline 3 & $60 \mathrm{~F}$ & $\begin{array}{l}\text { Breast, inappropriate } \\
\text { ADH }\end{array}$ & $\mathrm{Y}_{\mathrm{es}}$ & 1 & - & 2 & 7.2 & 5.3 & 1.9 & 1.3 & 27 & 21 & _ & - & 1.9 & 26 & 2 & 2 \\
\hline 4 & $75 \mathrm{~F}$ & $\begin{array}{l}\text { Squamous ceill, } \\
\text { bronchus }\end{array}$ & No & $x^{2}$ & 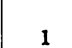 & 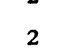 & 7.5 & 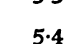 & 1.6 & 1.6 & 52 & 2. & 9 & 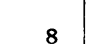 & 2.1 & 28 & 3 & 1 \\
\hline 5 & $65 \mathrm{~F}$ & Breast. & Yes \{ & $\frac{1}{2}$ & 10 & 1 & $\begin{array}{l}10.8 \\
7.5\end{array}$ & $\begin{array}{r}7.5 \\
5.0\end{array}$ & $\begin{array}{l}2 \cdot 1 \\
2 \cdot 8\end{array}$ & $\begin{array}{l}2 \cdot 8 \\
5 \cdot 3\end{array}$ & $\begin{array}{l}106 \\
110\end{array}$ & $\begin{array}{l}110 \\
110\end{array}$ & 12 & $\begin{array}{l}12 \\
15\end{array}$ & $\begin{array}{l}3.3 \\
2.5\end{array}$ & 30 & 6 & 5 \\
\hline 6 & $53 \mathrm{~F}$ & & Yes & $\bar{i}$ & $\begin{array}{r}15 \\
24 \\
9\end{array}$ & 三 & $\begin{array}{l}9.1 \\
8.2 \\
8.7 \\
5.8\end{array}$ & $\begin{array}{l}5.2 \\
4.9 \\
5.8\end{array}$ & $\begin{array}{l}1.3 \\
2.7 \\
2.8\end{array}$ & $\begin{array}{l}2 \cdot 1 \\
2 \cdot 1 \\
3.4 \\
2.1\end{array}$ & $\begin{array}{r}130 \\
180 \\
86 \\
60\end{array}$ & $\begin{array}{l}22 \\
50 \\
64 \\
55\end{array}$ & $\begin{array}{l}19 \\
\frac{19}{=}\end{array}$ & $\begin{array}{l}50 \\
7 \\
=\end{array}$ & $\begin{array}{r}3.9 \\
3.3 \\
2.9 \\
-0.8\end{array}$ & $\begin{array}{r}43 \\
40 \\
33 \\
\end{array}$ & $\begin{array}{l}9 \\
6 \\
6 \\
5\end{array}$ & $\begin{array}{l}\overline{1} \\
\frac{1}{3} \\
-\end{array}$ \\
\hline 7 & $59 \mathrm{~F}$ & Breast & Yes \{ & $\begin{array}{l}3 \\
4 \\
5 \\
6\end{array}$ & $\frac{7}{4}$ & $\begin{array}{l}\overline{2.3} \\
1.5\end{array}$ & $\begin{array}{l}5.8 \\
7.3 \\
7.8 \\
8.5\end{array}$ & $\begin{array}{l}6.6 \\
7.8 \\
6.8 \\
8.1\end{array}$ & $\begin{array}{l}2.7 \\
2.0 \\
2.6 \\
1.6\end{array}$ & $\begin{array}{l}2 \cdot 1 \\
2 \cdot 6 \\
2 \cdot 6 \\
2 \cdot 8\end{array}$ & $\begin{array}{l}52 \\
52 \\
56 \\
34\end{array}$ & $\begin{array}{l}55 \\
56 \\
32 \\
34\end{array}$ & 三 & 三 & $\begin{array}{r}-0.8 \\
-0.5 \\
1.0 \\
0.4\end{array}$ & 三 & $\begin{array}{l}5 \\
3 \\
2 \\
2\end{array}$ & 三 \\
\hline 8 & $45 \mathrm{~F}$ & Breast & Yes \{ & $\frac{1}{2}$ & $\begin{array}{r}5 \\
16\end{array}$ & 1.5 & $\begin{array}{l}8.8 \\
8.6\end{array}$ & $\begin{array}{l}6.8 \\
6.1\end{array}$ & $\begin{array}{l}2 \cdot 4 \\
1.8\end{array}$ & $\begin{array}{l}2 \cdot 7 \\
5.1\end{array}$ & $\begin{array}{l}70 \\
56\end{array}$ & $\begin{array}{l}43 \\
64\end{array}$ & $\begin{array}{l}10 \\
21\end{array}$ & $\overline{23}$ & $\begin{array}{l}2 \cdot 0 \\
2 \cdot 5\end{array}$ & $\begin{array}{l}23 \\
30\end{array}$ & $\stackrel{2}{7}$ & $\begin{array}{l}1 \\
1\end{array}$ \\
\hline 9 & $68 \mathrm{M}$ & Bladder & Prob. \{ & $\frac{1}{2}$ & 9 & 二 & $\begin{array}{l}8 \cdot 1 . \\
7 \cdot 1\end{array}$ & $\begin{array}{l}5 \cdot 4 \\
5 \cdot 7\end{array}$ & $\begin{array}{l}3 \cdot 4 \\
5 \cdot 1\end{array}$ & $\begin{array}{l}5.7 \\
5.8\end{array}$ & $\begin{array}{l}102 \\
224\end{array}$ & $\begin{array}{l}124 \\
148\end{array}$ & 二 & 二 & $\begin{array}{l}2.7 \\
1.4\end{array}$ & $\begin{array}{l}33 \\
20\end{array}$ & $\begin{array}{l}3 \\
6\end{array}$ & $\frac{1}{3}$ \\
\hline 10 & $45 \mathrm{~F}$ & $\begin{array}{lll}\text { Breast } & . & .\end{array}$ & Yes \{ & $\frac{1}{2}$ & $\begin{array}{r}11 \\
4\end{array}$ & $=$ & $\begin{array}{l}7 \cdot 4 \\
8 \cdot 7\end{array}$ & $\begin{array}{l}\mathbf{6 \cdot 2} \\
5 \cdot 9\end{array}$ & $\begin{array}{l}2 \cdot 1 \\
1 \cdot 9\end{array}$ & $\begin{array}{l}2 \cdot 0 \\
4 \cdot 5\end{array}$ & $\begin{array}{l}66 \\
63\end{array}$ & $\begin{array}{r}53 \\
100\end{array}$ & 46 & 33 & $\begin{array}{l}1 \cdot 2 \\
2 \cdot 8\end{array}$ & $\begin{array}{l}16 \\
32\end{array}$ & $\begin{array}{l}3 \\
3\end{array}$ & $\begin{array}{l}3 \\
1\end{array}$ \\
\hline 11 & $70 \mathrm{M}$ & $\begin{array}{l}\text { Lung, partly dirter- } \\
\text { entiated adeno- } \\
\text { carcinoma }\end{array}$ & No & 1 & 24 & - & 8.6 & 6.9 & 1.7 & $2 \cdot 8$ & 73 & 72 & - & - & 1.7 & 20 & 6 & 1 \\
\hline 12 & $66 \mathrm{M}$ & $\begin{array}{l}\text { Bronchus; cell type } \\
\text { not known }\end{array}$ & No & 1 & 4 & - & 6.8 & 6.6 & 1.6 & 1.35 & 16 & 12 & 15 & 16 & 0.2 & 3 & 3 & 3 \\
\hline 13 & $62 \mathrm{M}$ & $\begin{array}{l}\text { Squamous cell, } \\
\text { bronchus }\end{array}$ & No & 1 & 2 & 1 & 7.6 & 6.3 & 1.4 & 1.5 & 38 & 26 & 22 & 24 & 1.3 & 18 & 3 & 2 \\
\hline
\end{tabular}

" On phosphate" values are those at maximum calcium fall, as defined for Fig. 1. Normal range shown in parenthesis.

or even its discontinuance, was necessitated occasionally by gastrointestinal symptoms. The Table shows the response to 18 first or second courses of oral or intravenous therapy followed for two to nine days and the response to four further courses in one patient. Only the responses of the serum calcium and other measurements from the first two courses are included in the analyses that follow, as later courses do not reflect the phosphate treatment alone but the combined effect of ancillary measures and the patient's terminal state.

\section{Measurements Made}

Serum calcium, inorganic phosphate, alkaline phosphatase, urea, and sometimes electrolytes were followed as closely as possible. Venepuncture was with minimal or no stasis, usually at 8 to 9 a.m., before breakfast. The estimations were done in the department of chemical pathology, using flame spectrophotometry for serum calcium and autoanalyser for serum phosphate, serum alkaline phosphatase, and blood urea (Wootton, 1964). Therapy was monitored by daily serum calcium determinations until a downward trend was shown, and then about twice weekly to follow the serum calcium level after cessation of phosphate treatment. Reliable urine collections were precluded by our patients' poor general condition.

\section{Results}

The effects of phosphate therapy in each patient are summarized in the Table. The route of administration is indicated, and where multiple courses were given each has a new entry.

\section{Effect of Phosphate on Serum Calcium Level}

From the extent of the maximum fall observed (Fig. 1) it is evident that the treatment was nearly always very effective. Seven patients reached normal serum calcium levels; the rest showed decreases of 16 to $33 \%$ to reach levels of 5.7 to 7.5 $\mathrm{mEq} / 1$. (except Case 12, whose gastrointestinal symptoms permitted only about $1 \mathrm{~g}$. of oral phosphorus daily for three days).
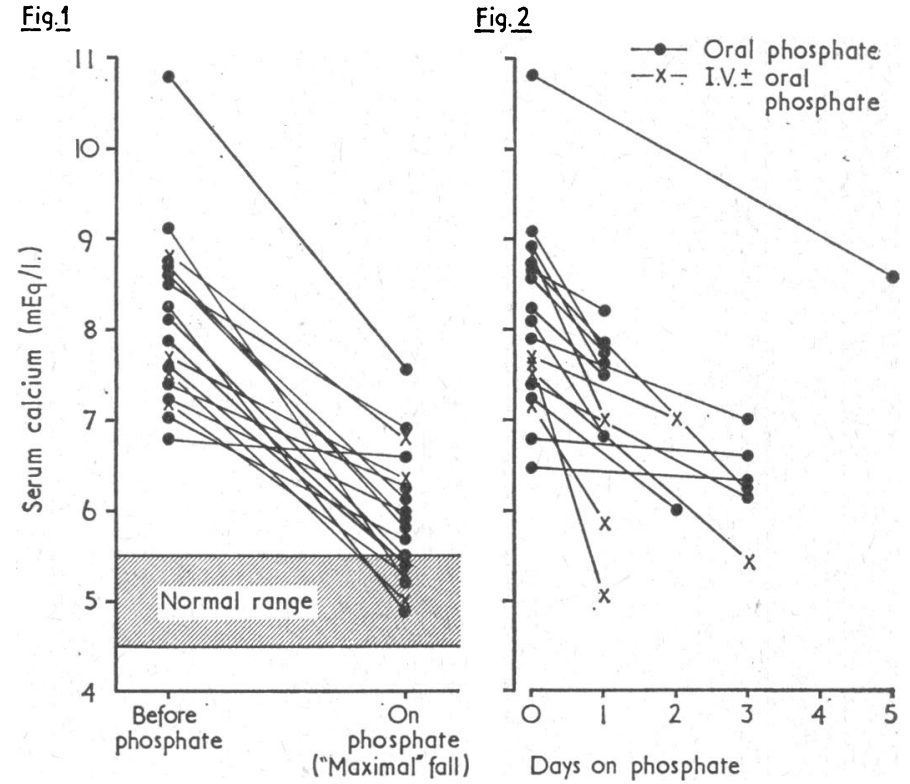

FIG. 1.-Extent of " maximal" fall in serum calcium (18 courses in 13 patients). The "before phosphate" sample was the last one taken before patients). The "before phosphate" sample was the last one taken before value achieved or, failing normalization, the lowest achieved. All of the value achieved or, failing normalization, the lowest achieved. All of the
patients' first and second courses are shown. FIG. 2.-Rapidity of response of hypercalcaemia (18 courses in 13 patients). The last sample taken before beginning phosphate is plotted at time zero for each course. The next value plotted is from the first venepuncture done after starting phosphate: a fall had invariably occurred.

The fall in the serum calcium was rapid, being evident at 24 hours in all of the nine courses sampled at that time, as is shown in Fig. 2.

In an uninterrupted course the maximal fall was attained at varying times. In nine courses (four of oral phosphate only) the maximum fall was achieved by three days, while the other eight courses (all oral) took four to nine days of treatment. The response to intravenous phosphate was probably a little faster than that to oral in that all patients treated intravenously had achieved maximal effect within three days of phosphate 
Eig. $\underline{3}$

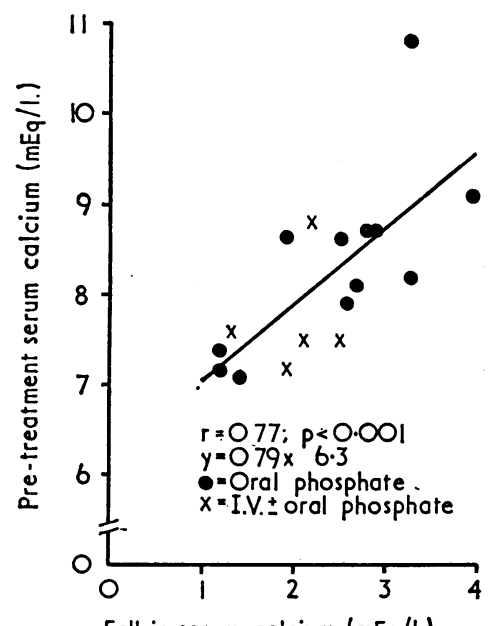

Fig. 4

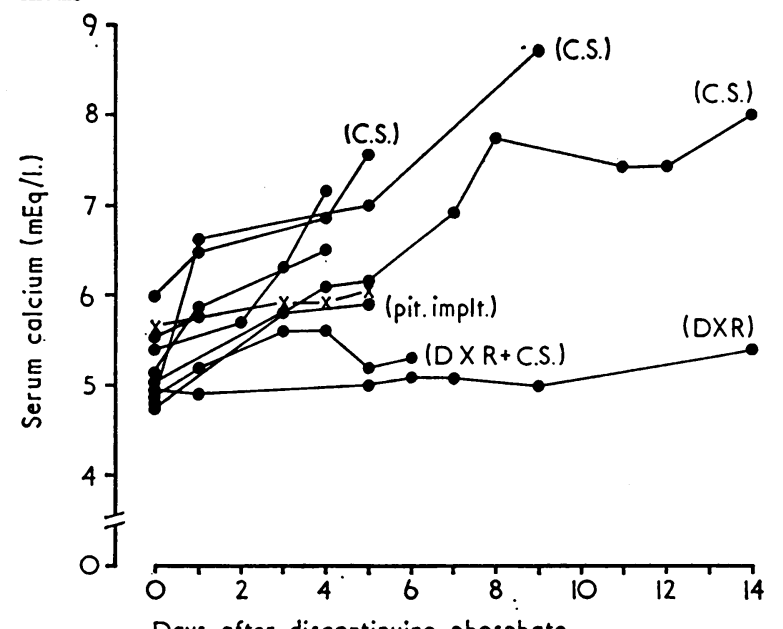

Doys ofter discontinuing phosphate

FIG. 3.-Correlation between pretreatment levels of serum calcium and fall due to phosphate (17 courses in 12 patients). Fall in serum calcium plotted is that from the pretreatment level to the lowest level reached on phosphate therapy, whether oral $(O)$ or intravenous $(x)$. FIG. 4 . - Serum calcium after discontinuing phosphate therapy (10 courses in nine patients). Discontinuation of phosphate therapy was followed (a) to assess effectiveness of other more definitive treatment, such as pituitary destruction (pit. implt.), or radiotherapy (DXR), or because of side-effects. Any ancillary corticosteroid (C.S.) therapy used is shown. One patient with hyperparathyroidism $(+-+)$ is included.

treatment, as opposed to the majority of oral courses requiring more than this time. The time required to reach this lowest level of serum calcium was not very closely related to the initial serum calcium level in these 17 courses.

Clearly the extent of the initial hypercalcaemia defines the fall attainable. The maximum decrease observed (in $\mathrm{mEq} / \mathrm{l}$.), whether on oral or intravenous phosphate, appears (Fig. 3) to be directly proportional to the initial serum calcium level $(\mathrm{r}=0.77 ; \mathrm{P}<0.001)$.

The serum calcium was followed on 10 occasions after discontinuation of phosphate therapy. It is seen in Fig. 4 that all the patients who were not given radiotherapy showed a relapse in serum calcium, sometimes within 24 hours. Cases 3 and 6, who were given radiotherapy, maintained a normal serum calcium for the several days they were followed after the last dose of phosphate.

\section{Serum Inorganic Phosphate During Therapy}

The serum inorganic phosphate concentration was followed on the same blood samples as referred to above with respect to the serum calcium. Fig. 5 shows the values obtained just before treatment, and again on phosphate therapy when the

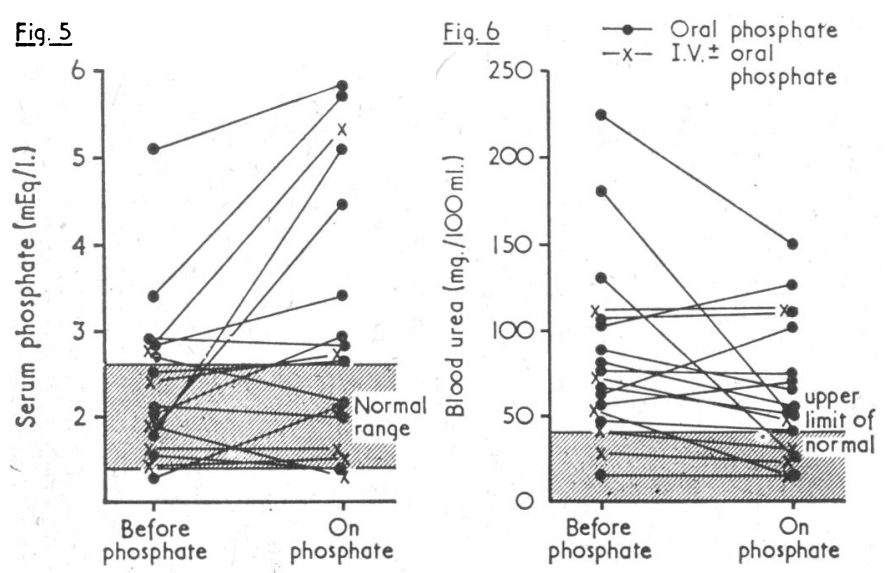

FIG. 5.- Serum inorganic phosphate levels before treatment and at time of maximal hypocalcaemic effect (17 courses in 12 patients). Blood camples were those of Fig. 1. FIG. 6.- Blood urea levels before treatment and at time of maximal hypocalcaemic effect (18 courses in 13 patients). Blood samples were those of Fig. 1. serum calcium first reached normal or the lowest value was achieved. In the majority of patients the initial level was under $3 \mathrm{mEq} / \mathrm{l}$. and the final level had changed little. In all the five courses in which the final serum phosphate was over $4 \mathrm{mEq} / \mathrm{l}$. there had been raised blood urea before treatment; however, several other uraemic patients did not show this rise. The rise in serum phosphate at the end of the intravenous phosphate infusions disappeared in the next 24 hours in nonuraemic patients.

\section{Blood Urea Level During Therapy}

Change in the blood urea during the 18 courses studied (13 patients) is summarized in Fig. 6 . In all but three instances the blood urea level remained unchanged or fell ; there were three falls of over $60 \mathrm{mg} . / 100 \mathrm{ml}$. Slight rises were seen in three courses in patients with complicating features such as bladder obstruction or terminal malignancy.

\section{Serial Data in an Illustrative Case}

The clinical and biochemical progress of Case 7, who had carcinoma of the breast and massive metastases, is shown in Fig. 7. She illustrates many of the features reported in this paper, but was atypical in that she survived long enough to be treated by as many as six courses. It is seen that she had developed hypercalcaemia during the month before her admission on 20 August 1966 . She had rapidly become critically ill with uraemia, along with a low serum potassium $(2.7 \mathrm{mN})$ and high bicarbonate $(39 \mathrm{mN})$ as is often seen in such hypercalcaemic patients. It was decided to treat her by yttrium-90 pituitary implantation if her general condition could be improved. Initial treatment with fluids and prednisone 40 mg./day had little immediate effect, so after four days oral phosphate (4 g. of phosphorus daily) and oral potassium (24 $\mathrm{mEq} /$ day) was added. The serum calcium, urea, and bicarbonate all rapidly fell to normal, and her clinical improvement now permitted the operation.

Phosphate was discontinued on the second postoperative day to assess the efficacy of the pituitary implant. Unfortunately, hypercalcaemia and uraemia reappeared, possibly because of inadequate pituitary ablation, for the ${ }^{131} I$ uptake by the thyroid remained normal. Oral phosphate was resumed on 13 October, 


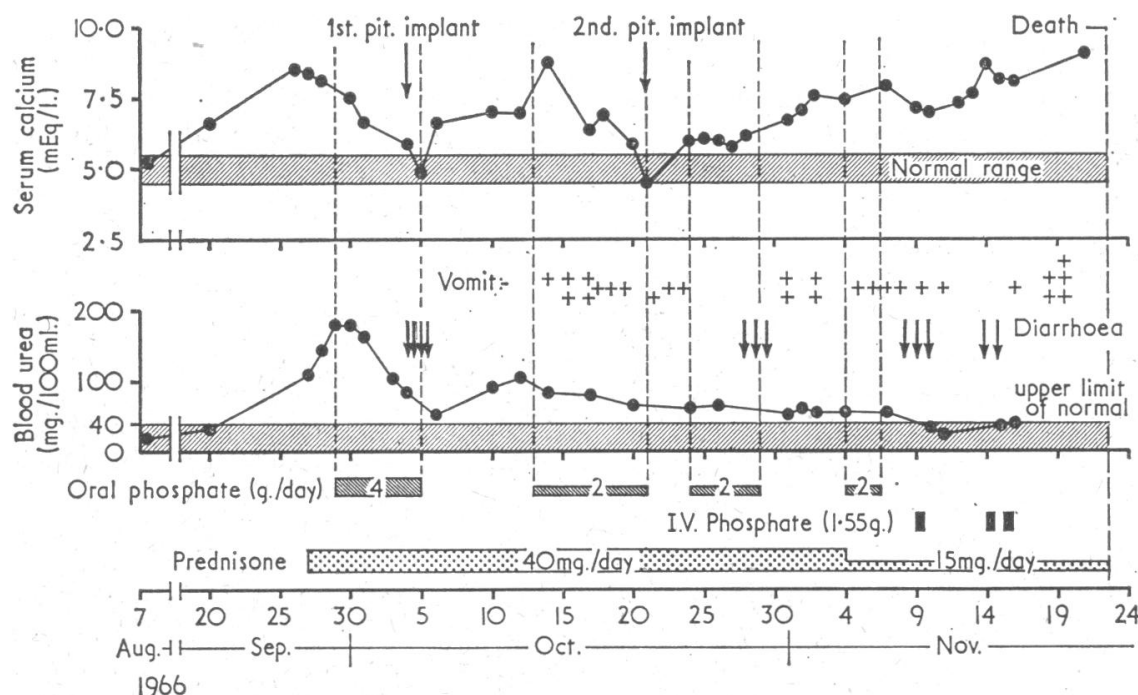

FIG. 7.-Effect of phosphate therapy on hypercalcaemia and blood urea in Case 7 (metastatic breast cancer). Oral phosphate was initially effective in doses of 4 and $2 \mathrm{~g}$. of phosphorus daily. Later, neither oral nor intravenous phosphorus prevented advancing hypercalcaemia. Prednisone $40 \mathrm{mg}$. daily was probably ineffective, as was pituitary implantation. life, no evidence of corneal calcification was found microscopically.

\section{Discu'ssion}

All of these hypercalcaemic patients with cancer responded favourably to the administration of an adequate course of inorganic phosphate; seven achieved a normal serum calcium and the rest showed a significant decrease. Concomitant with the fall in the serum calcium the serum phosphate was largely unchanged, while the blood urea also often fell and only rarely rose. Along with the biochemical evidence of amelioration of the hypercalcaemia, in most patients there was a striking clinical improvement. Some patients-for example, Cases 1 and 3-who looked moribund before treatment were able to eat and drink after 48 hours on phosphate, and later became ambulant.

Our findings with respect to the response of the serum calcium are in general agreement with other authors who have used

2 g. of phosphorus being given daily because diarrhoea had occurred with $4 \mathrm{~g}$. of phosphorus daily in the first course. Again there was a brisk fall in serum calcium to normal. Reimplantation was done on 20 October, but by this time she was in the terminal phase of the disease and henceforth neither oral nor intravenous phosphate was effective in preventing the serum calcium from increasing, though uraemia did not recur.

\section{Clinical Effects of Phosphate Therapy}

Side-effects.-These were confined to gastrointestinal symptoms from oral administration, comprising epigastric pain, nausea, and diarrhoea. The higher the dose of oral phosphate the more frequent and more obvious the symptoms. Sometimes these could be better controlled by distributing the phosphate in smaller and more frequent doses, or by symptomatic treatment, but the only successful measure sometimes was to discontinue administration temporarily and, if necessary, continue by the intravenous route.

Effect on Symptoms Due to Hypercalcaemia.-The beneficial effect of the phosphate treatment on the hypercalcaemic symptoms was apparent in all the treated patients whose serum calcium fell-that is, all except Case 12 . The patients' clinical improvement paralleled the biochemical improvement, and seemed to antedate the latter by about a day.

\section{Necropsy Findings}

Eight of the 13 hypercalcaemic patients with malignant hypercalcaemia came to necropsy. None showed evidence of excessive calcification within the blood vessels and only two showed microscopical nephrocalcinosis. These two patients had had severe hypercalcaemia (Case 11, for more than one month and Case 10 for more than two months before being seen by us) and corneal calcification was noted in both before treatment with inorganic phosphate; both patients also had mild uraemia when first seen and both were treated with oral phosphate only. Unfortunately they succumbed from other effects of cancer after only a few days of phosphate treatment.

Of the eight patients who came to necropsy six had had corneal calcification noted by us in life before any treatment with inorganic phosphate had been given; this clinical observation was confirmed by microscopy in the three cases in which it was looked for. In the other two patients who came to necropsy in whom we had not found corneal calcification in inorganic phosphate treatment of hypercalcaemia (Bulger et al., 1931 ; Albright et al., 1932 ; Dent, 1962 ; Goldsmith and Ingbar, 1966 ; Hebert et al., 1966 ; Kahil et al., 1967 ; Kistler, 1967 ; Massry et al., 1968). While the effective reduction of the rise in serum calcium has been a universal finding, the effect on the serum phosphate has been controversial. We have found little change in serum phosphate with non-uraemic patients. Bulger et al. (1931) found an increase in the serum phosphate when they used oral inorganic phosphate in the treatment of hyperparathyroidism, but that increase was from subnormal to normal values, and our case of inoperable primary hyperparathyroidism responded similarly (see Appendix). Goldsmith and Ingbar (1966) found no significant change in the serum phosphate in their patients with cancer at the stage that the serum calcium became normal, though some of them were treated with repeated intravenous infusions. Likewise, Hebert et al. (1966), Kahil et al. (1967), and Kistler (1967) all found that in their cancer patients the increase in serum phosphate near the end of an infusion came back to preinfusion values within hours.

There was no striking difference in the effect of oral or intravenous administration; probably the intravenous route is more rapidly effective. Thus phosphate need be given intravenously only in those few cases where the patient's condition does not at first permit the oral route. Such ill patients may have the highest levels of serum calcium, and so may benefit especially from the prompt reduction of the hypercalcaemia. We have never found more than a total of $2 \mathrm{~g}$. of phosphorus required intravenously. Similarity in the effect of oral and intravenous phosphate was also found by Goldsmith and Ingbar (1966) and Massry et al. (1968), but not by Kahil et al. (1967) and Kistler (1967), who found no effect from oral administration on serum calcium, though they did find a reduction in urinary calcium. It is difficult to explain their negative results, as our patients obtained a hypocalcaemic effect with even smaller daily doses of phosphate.

The therapeutic effect of inorganic phosphate on hypercalcaemia of malignant disease persisting after the general measures of dietary calcium restriction and rehydration can be quite dramatic. Most of our patients had a preliminary period of treatment confined to these conventional measures; hence it is surprising that, although it was used successfully 35 years ago in connexion with hyperparathyroidism (Bulger et al., 1931 ; Albright et al., 1932), it had been largely abandoned until recently. This may have been partly due to a general unawareness of the frequency and clinical importance of "malignant" hypercalcaemia. In the meantime chelating agents, and 
especially edetic acid, have been used (Spencer et al., 1952 ; Holland et al., 1953), though it is clear that repeated infusions had deleterious effects on the renal function (Dudley et al., 1955 ; Foreman et al., 1956). Sodium citrate infusions (Kennedy et al., 1953) have been used in an attempt to treat high serum calcium, but their effect lasts for only a few hours.

Corticosteroids have been widely accepted as a useful treatment of the hypercalcaemia of malignant disease (Connor et al., 1956 ; Watson, 1964) but are clearly less generally effective than phosphate, as instanced in Fig. 7. Also the response is too slow to be useful for critically severe hypercalcaemia (Gleckler, 1956), and a number of cases have failed to respond to this treatment (Connor et al., 1956 ; Thomas et al., 1958), as we also have found. Sodium sulphate (Lemann and Mehr, 1965; Chakmakjian and Bethune, 1966) has been fairly effective, but its practical use is limited by the need to confine its administration to intravenous infusions, while hypernatraemia is a hazard from the very large sodium content (Heckman and Walsh, 1967).

Infusions of chelating agents, sodium citrate, and sodium sulphate all act partly or wholly by producing an increase in urinary calcium (Wolf and Ball, 1950; Chakmakjian and Bethune, 1966). On the contrary, inorganic phosphate lowers the urine calcium (Hebert et al., 1966; Kistler, 1967) and the calcium clearance (Massry et al., 1968), and so must act by an increase in calcium deposition in bone or ectopic sites, or by a reduction in bone resorption. Ignorance regarding which of these mechanisms is taking place has been the cause for hesitation in the use of inorganic phosphate.

Hebert et al. (1966) suggested that the observed decrease in the serum calcium ought to be attributed to increased precipitation of calcium salts, due to tne increased solubility product resulting from a phosphate infusion. On the other hand, Pechet et al. (1967), working with thyroparathyroidectomized rats, concluded that the mechanism of action is by increasing true bone formation as evidenced by radioisotope and histological studies. In addition, an enhancement of the action of calcitonin, as reported by Hirsch (1968), may reduce the bone resorption rate. Some reported evidence in man suggests that extraskeletal calcification is not increased after phosphate administration : Goldsmith and Ingbar (1966) considered that the calcification found in some of their phosphate-treated patients was not excessive in view of the long-standing hypercalcaemia ; Kahil et al. (1967) compared five hypercalcaemic patients treated by intravenous inorganic phosphate with five hypercalcaemic patients who were never treated with phosphate, and found no increased incidence at necropsy of extraskeletal calcification, while in only two of them was there any evidence of microscopical nephrocalcinosis.

Neither Dent's (1967) case of inoperable hyperparathyroidism on long-term phosphate treatment nor our own case (see Appendix) has shown clinical or radiological evidence of ectopic calcification. Furthermore, Bernstein and Newton (1966) have now reported on long-term phosphate therapy for stoneformers ; up to five years of treatment has not produced any clinical or radiological evidence of ectopic calcification. Hebert et al. (1966) demonstrated radiologically some calcium deposition in the vein into which phosphate was infused in three out of seven patients with cancer and hypercalcaemia ; this in itself is not a proof of general extraskeletal calcification due to phosphate, since calcification is a non-specific response to injury, and these veins were exposed to extremely high concentrations of phosphate.

It therefore seems to us that oral inorganic phosphate $(1 \mathrm{~g}$. of phosphorus three times daily) is the treatment of choice for the short-term palliation of malignant hypercalcaemia, occasionally preceded by an intravenous infusion $(1 \mathrm{~g}$. of phosphorus over eight hours) where the general clinical condition necessitates this route. Treatment is adequately monitored by daily serum calcium estimations until a downward trend is shown, and then it must be followed about twice weekly, after discontinuing phosphate to detect any subsequent relapse. Hypokalaemia, which occurs quite of ten, should also be sought when hypercalcaemia is found.

\section{Appendix}

Long-term Administration of Phosphate in Patient with Inoperable Primary Hyperparathyroidism.-This patient has had long-standing hypercalcaemia due to hyperparathyroidism, but operation has twice failed to reveal an adenoma. No skeletal changes of hyperparathyroidism are seen radiologically. In view of the raised serum calcium (mean value $6.2 \mathrm{mEq} / 1$.) and his vague lack of energy, he was started on phosphate at a dose of $3 \mathrm{~g}$. of elemental phosphorus per day in October 1964. Fig. 8 summarizes the progress of this patient, who has been on oral phosphate treatment for more than three years. The serum calcium soon fell and he felt fitter. When treatment was withheld in January 1965 to check its efficacy, the serum calcium rose to the pretreatment level within five days and serum phosphate dropped to subnormal levels. On restarting treatment near-normal levels of both serum calcium and phosphate concentrations were obtained. During a four-month trial on a lower dose of $1.5 \mathrm{~g}$. of phosphorus per day both serum calcium and phosphate became more abnormal, but reverted again to nearly normal when the previous dose of $3 \mathrm{~g}$. of phosphorus per day was resumed. During phosphate treatment the urinary calcium was 5 to $10 \mathrm{mEq} /$ day, but on the temporary discontinuation of treatment it shot up to the highly abnormal output of $20 \mathrm{mEq} /$ day. Seven days after reinstitution of treatment urine calcium again fell (14 $\mathrm{mEq} /$ day). During the whole course of treatment the blood urea has been normal, and no evidence of corneal or renal calcification has appeared. He occasionally has to omit a dose of phosphate on account of diarrhoea.

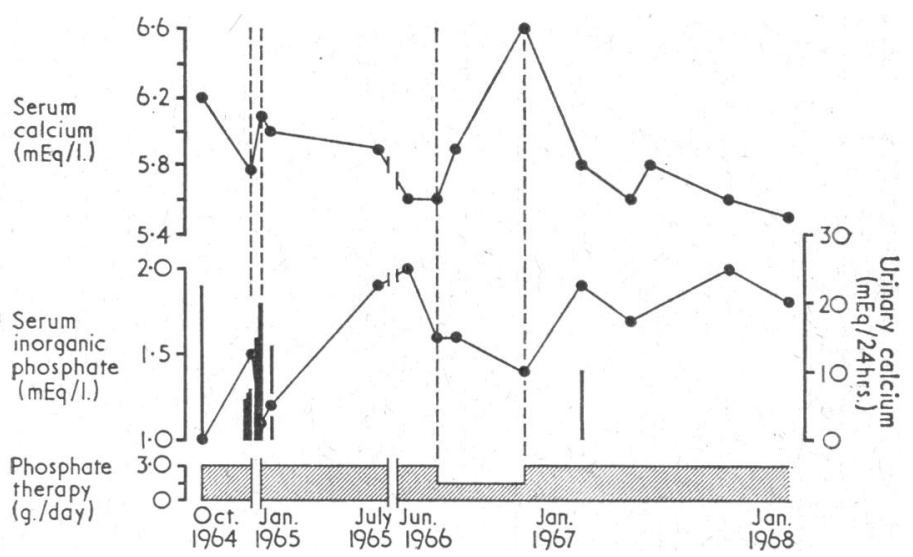

Fig. 8.-Long-term phosphate treatment in inoperable primary hyperparathyroidism. Near normal levels of serum calcium and phosphate are maintained by oral phosphate therapy at $3 \mathrm{~g}$. of phosphorus daily.

Acknowledgements.-We are grateful to the physicians and surgeons of Hammersmith Hospital who encouraged us in the study and treatment of patients under their care, and to the nursing and junior medical staff who exceeded their duty in assisting us with record-keeping and patient-management. We are also grateful to the Department of Morbid Anatomy for the use of their postmortem reports. We wish to thank Professor Russell Fraser for his helpful criticism of the manuscript.

One of us (N. T.) was supported by a World Health Organization Fellowship, and the other (G. F. J.) by a Wellcome Senior Clinical Research Fellowship.

\section{REFERENCES}

Albright, F., Bauer, W., Claflin, D., and Cockrill, J. R. (1932). f. clin. Invest., 11, 411 .

Albright, F., and Reifenstein, E. C. (1948). The Parathyroid Glands and Metabolic Bone Disease. Baltimore.

Bernstein, D. S., and Newton, R. (1966). Lancet, 2, 1105.

Binger, C. (1917-18). f. Pharmacol. exp. Ther., 10, 105.

Bulger, H. A., Dixon, H. H., Barr, D. P., and Schregardus, O. (1931). 7. clin. Invest., 9, 143 . 
Chakmakjian, Z. H., and Bethune, J. E. (1966). New Engl. 7. Med., 275, 862.

Connor, T. B., Hopkins, T. R., Thomas, W. C., jun., Carey, R. A., and Howard, J. E. (1956). F. clin. Endocr., 16, 945.

Dent, C. E. (1962). Brit. med. F., 2, 1495.

Dent, C. E. (1967). Lancet, 2, 613.

Drivsholm, Aa., and Videbæk, Aa. (1966). Acta med. scand., 179, Suppl. No. 445 , p. 187.

Dudley, H. R., Ritchie, A. C., Schilling, A., and Baker, W. H. (1955). New Engl. Ұ. Med., 252, 331 .

Foreman, H., Finnegan, C., and Lushbaugh, C. C. (1956). F. Amer. med.

Ass., 160, 1042. (1968). Calcitonin : Proceedings of the Symposium
Foster, G. V., et al. (1968) on Thyrocalcitonin and the C Cells, edited by S. Taylor, p. 379. London.

Gleckler, W. J. (1956). Ann. intern. Med., 44, 174.

Goldsmith, R. S., and Ingbar, S. H. (1966). New Engl. F. Med., 274, 1. Hebert, L. A., Lemann, J., jun., Petersen, J. R., and Lennon, E. J. (1966). f. clin. Invest., 45, 1886 .

Heckman, B. A., and Walsh, J. H. (1967). New Engl. F. Med., 276, 1082.

Henson, R. A. (1966). 7. roy. Coll. Phycns, 1, 41.

Hirsch, P. F. (1968). Calcitonin: Proceedings of the Symposium on Thyrocalcitonin and the $C$ Cells, edited by $S$. Taylor, p. 11. London.

Holland, J. F., Danielson, E., and Sahagian-Edwards, A. (1953). Proc. Soc. exp. Biol. (N.Y.), 84, 359.
Joplin, G. F. (1965). Thesis submitted to University of London for Ph.D., p. 302.

Kahil, M., Orman, B., Gyorkey, F., and Brown, H. (1967). F. Amer. med. Ass., 201, 721 .

Kennedy, B. J., Tibbetts, D. M., Nathanson, I. T., and Aub, J. C. (1953). Cancer Res., 13, 445 .

Kistler, H. J. (1967). Helv. med. Acta, 33, 447.

Lemann, J., jun., and Mehr, M. P. (1965). Ұ. Amer. med. Ass., 194, 1126

Massry, S. G., Mueller, E., Silverman, A. G., and Kleeman, C. R. (1968). Clin. Res., 16, 128.

Pechet, M. M., Bobadilla, E., Carroll, E. L., and Hesse, R. H. (1967). Amer. F. Med., 43, 696.

Plimpton, C. H., and Gellhorn, A. (1956). Amer. F. Med., 21, 750.

Salvesen, H. A., Hastings, A. B., and McIntosh, J. F. (1924). f. biol. Chem., 60, 311 .

Spencer, H., Vankinscott, V., Lewin, I., and Laszlo, D. (1952). F. clin. Invest., 31, 1023.

Thomas, W. C., jun., Connor, T. B., and Morgan, H. G. (1958). 7. Lab. clin. Med., 52, 11 .

Watson, L. (1964). Quart. 7. Med., 33, 525.

Watson, L. (1966). Aust. Ann. Med., 15, 359.

Wolf, A. V., and Ball, S. M. (1950). Amer. F. Physiol., 160, 353.

Wootton, I. D. P. (1964). Micro-analysis in Medical Biochemistry, 4th ed. London.

\title{
Puerperal Thromboembolism in Relation to the Inhibition of Lactation by Oestrogen Therapy
}

\author{
T. N. A. JEFFCOATE,* M.D., F.R.C.S.ED., F.R.C.o.G. ; JANINE MILLER,* M.B., CH.B., M.R.C.o.G. \\ R. F. ROOS,* M.B., CH.B., M.R.C.o.G. ; V. R. TINDALL, † M.D., F.R.C.S.ED., M.R.C.O.G.
}

Brit. med. F., 1968, 4, 19-25

\begin{abstract}
Summary : An analysis was made of 111 consecutive $\checkmark$ cases of puerperal thromboembolism by the age, parity, mode of delivery, and lactation habit of the women concerned, and the findings were compared with those from control groups.
\end{abstract}

The statistics show that inhibition of lactation by means of ethinyloestradiol is associated with a threefold increase in thromboembolism, although the effect is seen mainly in women who have an operative delivery and who are aged more than 25 years. Among women aged more than 35 years who have an assisted delivery, inhibition of lactation is accompanied by a tenfold increase in the incidence of puerperal thromboembolism.

Advancing age and operative intervention (especially caesarean section) are in themselves predisposing causes of deep venous thrombosis and embolism. They can also constitute indications for inhibiting lactation. This makes it difficult to assess whether the relation of thromboembolism to inhibition of lactation or to the administration of oestrogen is real or apparent. Doubts on the interpretation of the findings are raised by the fact that the number of fatal cases of puerperal thromboembolism in England and Wales, and of non-fatal cases in the hospitals under review, has not increased in recent years despite a progressive decrease in breast-feeding. Nevertheless, the evidence suggests that although the administration of ethinyloestradiol is not by itself enough to cause puerperal thromboembolism, it may be a factor which can tip the scales in women who are already predisposed to suffer this condition.

Any thromboembolic hazard associated with administration of oestrogens for inhibiting lactation is probably acceptable except in women known to be at special risk by reason of age, operative delivery, obesity, and a past history of thromboembolic episodes.

\section{Introduction}

It was first suggested by Daniel, Campbell, and Turnbull (1967) that suppression (or inhibition) of lactation favours the development of deep venous thrombosis and embolism in puerperal women. From information derived from the Cardiff Birth Survey these workers concluded that the inhibition of lactation in mothers aged 25 and more is associated with a tenfold increase in the incidence of thromboembolism, and postulated that the administration of oestrogen may play a part in this. Following this, Daniel, Bloom, Giddings, Campbell, and Turnbull (1968) showed that the administration of relatively large amounts of diethylstilboestrol increases the coagulability of blood by raising the level of factor IX. In the original Cardiff series the oestrogen used was diethylstilboestrol administered in divided doses up to a total of 210-330 mg. during the course of nine days. This dosage, it may be noted, is higher than is usually given, and work carried out many years ago indicated that a total of $45-50 \mathrm{mg}$. of diethylstilboestrol during four to seven days is generally adequate to inhibit lactation (Jeffcoate, Lister, Hargreaves, and Roberts, 1948).

There are some who question the efficacy of oestrogen therapy to inhibit lactation, irrespective of dosage, and the literature pertaining to this was reviewed by Hodge (1967). Differences in experience and opinion may in large measure reflect the timing of the administration of the hormone. The evidence suggests that the sooner after delivery oestrogen is given the more likely is it to inhibit breast activity. Oestrogens will not suppress lactation which is already established. Whatever be their efficacy, there is no question that oestrogens are widely used with the object of inhibiting or suppressing lactation, and it is therefore of considerable importance to determine whether all or certain of the preparations available predispose to puer-

\footnotetext{
* Department of Obstetrics and Gynaecology, University of Liverpool, Liverpool 3.

t Department of Obstetrics and Gynaecology, the Welsh National School of Medicine, Cardiff.
} 